\title{
Employing International Graduates in the Sciences: U.S. Visa Options
}

\section{Victoria Donoghue and David Nachman}

Many U.S. employers have an interest in hiring college and professional school graduates who were not born in the United States. This is true in every field, but is particularly so in the sciences because the pool of U.S. scientists is diminishing. Quite often, hiring international scientists is necessary to continue to produce high-quality research. All the same, employers often shy away from hiring international graduates because they are intimidated by many of the complex U.S. immigration laws.

In reality, hiring international graduates in the sciences is not very difficult and the potential rewards are enormous; individuals from around the globe help U.S. employers to perform cutting-edge research. Hiring international graduates involves only a basic understanding of the visa options available. While there are many temporary visa classifications available, those outlined below may be useful options to consider when an employer wants to hire an international graduate educated in the sciences.

\section{Limited-Stay Visas:}

\section{$\mathrm{F}, \mathrm{J}, \mathrm{H}-1 \mathrm{~B}$, and $\mathrm{O}$}

When a student is in a bachelor's, master's, or doctoral program and has completed all course requirements for a degree in science, technology, engineering, or math, he or she is eligible for a 29 month period of Optional Practical Training. The application process involves obtaining permission from the academic institution and requesting work authorization, or an EAD, from the U.S. Citizenship \& Immigration Services (USCIS). The EAD allows a student to engage in free market employment.

$\mathrm{J}-1$ students are eligible for academic training after graduation. Academic training provides an opportunity to apply theoretical knowledge obtained in an academic program to a practical work experience. Doctoral students who obtain a post-doc position may be eligible for academic training. Employment must be authorized by the Responsible Officer at the academic institution.

The H-1B visa program is intended to permit U.S. employers to hire highly educated employees for "specialty occupations" (positions that require at least a bachelor's degree in a specialized field). Examples include research associates, engineers, and computer professionals. The period of stay for $\mathrm{H}-1 \mathrm{~B}$ holder is 6 years, and an application must be made to USCIS. Extensions beyond 6 years may be possible under certain circumstances. There is a cap of $65,000 \mathrm{H}-1 \mathrm{~B}$ visas available per year, and demand for these visas often outstrips supply. However, institutions of higher education and nonprofit or governmental research organizations are exempt from the cap.

Those who have demonstrated extraordinary ability in the sciences may be able to receive an $\mathrm{O}$ visa to work in their area of expertise. By way of example, a graduate with a Ph.D. in civil engineering and a list of publications and presentations might be eligible for an $\mathrm{O}$ visa. Applications must be made to USCIS and the period of stay for an $\mathrm{O}$ visa is 3 years with incremental extensions available.

Each of the above visas is associated with a limited period of stay in the United States. An employer who has hired a scientist pursuant to one of these visas, and is pleased with that scientist's work, will quickly learn that time flies. In order to retain the scientist, the employer will have to sponsor the individual for lawful permanent residence status, or a "green card." Lawful permanent resi- dents are permitted to live and work in the United States indefinitely.

\section{Other Visa Options}

U.S. Immigration law permits scientists to apply for a green card, or immigrant visa, based upon their educational level and ability. While there are several ways to obtain an employment-based immigrant visa, the following options should be considered by scientists.

Outstanding Researchers and Professor visas are offered to scientists who show that they are outstanding, or have attained international recognition. The applicant will have to provide evidence of two of the following six groups: receipt of major prizes or awards, membership in associations that require outstanding achievements, authorship of scholarly articles, published material written about the scientist's work, original contributions to the field, service as a judge of the work of others, and presentations at international symposia.

National Interest Waivers are for scientists who perform research that has "substantial intrinsic merit" and is national in scope. They also have to establish "some degree of influence in the field." By way of example, a scientist who is performing research into a potential drug therapy for autism and has published in the area might be eligible.

Schedule A, Group II sets aside immigrant visas for persons of exceptional ability in the sciences. The evidentiary requirements are similar to those for the Outstanding Researcher category, but tend to be adjudicated in a less stringent manner.

Victoria Donoghue and David Nachman are with Nachman \& Associates, PC, Immigration and Nationality Law, with offices in New Jersey, New York, and Toronto. Donoghue can be reached at Victoria_Donoghue@visaserve.com. 